\title{
Histoultramicroscopic Investigation of the Rats' Thymus (Experimental Data)
}

\author{
Siçanların Timusunun Histoultramikroskopik İncelenmesi (Deneysel Veri)
}

\author{
Olha PRYKHODKO 1 \\ (D) 0000-0001-6215-891X \\ Serhii DMYTRUK ${ }^{1}$ \\ (D) 0000-0001-6434-2817 \\ Olga AVILOVA ${ }^{2}$ \\ (1) 0000-0003-4508-8336 \\ Eliska KUBIKOVA ${ }^{3}$ \\ (1) 0000-0002-8370-9618 \\ Valentyna BUMEISTER ${ }^{1}$ \\ (1) 0000-0001-8604-4458 \\ Olha YARMOLENKO ${ }^{1}$ \\ (D) 0000-0002-7872-2308 \\ Olena GORDIENKO ${ }^{1}$ \\ (D) 0000-0002-9408-8415
} State University, Sumy, Ukraine

${ }^{2}$ Department of Human Anatomy, Kharkiv National Medical University, Kharkiv, Ukraine

${ }^{3}$ Institute of Anatomy, Comenius University in Bratislava Faculty of Medicine, Bratislava, Slovakia
${ }^{1}$ Department of Morphology, Sumy

\begin{abstract}
Aim: The research paper presents the characteristic of cytoarchitectonics of the thymus of intact white mature male laboratory rats. Topicality of the study is due to the need to clarify the data on the contribution of each type of thymus cells in the formation of its structure. The aim of the research was to determine the specifics of localization and ultramicroscopic structure of thymus cells in male mature Wistar laboratory rats.

Material and Methods: The study was conducted using histological and ultramicroscopic methods on 10 mature male laboratory rats, weighing $130-150 \mathrm{~g}$. Semi-thin $(0.5-1 \mu \mathrm{m})$ and ultrathin $(0.05-0.2 \mu \mathrm{m})$ sections were made on a microtome UMTP-4 (Ukraine), which were stained with $1 \%$ methylene blue solution with the addition of $1 \%$ sodium tetraborate solution. Histological analysis and photographic recording were performed using Olympus light microscope (Japan) and DSM 510 camcorder with magnification in 1000 times.

Results: With a detailed study of the semi-thin and ultrathin sections in the thymus lobules the specifics of localization and ultramicroscopic structure of thymus cells were clearly identified. The features of localization and ultramicroscopic structure of epithelial, mesenchymal, vascular and hematopoietic thymus cells were determined from the point of view of their functional loads and interactions.

Conclusion: The described structural peculiarities of the components of the thymus and their relative location in different zones reflect significant organ polymorphism, which must be taken into account in order to achieve the required level of objectivity in the result evaluation of simulated biomedical experiments.

Keywords: Thymus gland; rats; histology; ultrastructure; experiment.
\end{abstract}

\section{ÖZ}

Amaç: $\mathrm{Bu}$ araştırma makalesi, sağlam beyaz olgun erkek laboratuvar sıçanlarının timusunun sitoarkitektonik özellikleri hakkında bilgi sunmaktadır. Çalışmanın güncelliği, her bir timus hücresi tipinin timüs yapısının oluşumuna olan katkısı hakkındaki verilerin net bir şekilde ortaya çıkarılmasına olan ihtiyaçtan kaynaklanmaktadır. Bu araştırmanın amacı, erkek olgun Wistar laboratuvar sıçanlarında timus hücrelerinin lokalizasyon ve ultramikroskopik yapısının özelliklerini belirlemektir.

Gereç ve Yöntemler: Bu çalışma, 130-150 g ağırlığındaki 10 olgun erkek laboratuvar sıçanı üzerinde histolojik ve ultramikroskopik yöntemler kullanılarak yapıldı. Bir UMTP-4 (Ukrayna) mikrotomu ile yarı ince $(0.5-1 \mu \mathrm{m})$ kesitler ve ultra ince $(0.05-0.2 \mu \mathrm{m})$ kesitler yapıldı, yapılan bu kesitler \%1 sodyum tetraborat solüsyonu ilave edilerek \%1 metilen mavisi

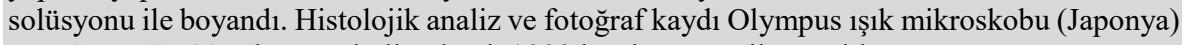
ve DSM 510 video kamera kullanılarak 1000 kez büyütme ile yapıldı.

Bulgular: Timus lobüllerindeki yarı-ince kesitler ve ultra-ince kesitlerin detaylı bir şekilde incelenmesi ile timus hücrelerinin lokalizasyon ve ultramikroskobik yapısının özellikleri net bir şekilde ortaya çıkarıldı. Epitelyal, mezenkimal, vasküler ve hematopoetik timus hücrelerinin lokalizasyon ve ultramikroskopik yapısının özellikleri, bu hücrelerin fonksiyonel yükleri ve etkileşimleri açısından dikkate alınarak belirlendi.

Sonuç: Timusun bileşenlerinin tanımlanmış yapısal özellikleri ve farklı bölgelerdeki göreceli konumları, simüle edilmiş biyomedikal deneylerin sonuçlarının değerlendirilmesinde gerekli olan ve istenen nesnellik düzeyinin elde edilebilmesi için dikkate alınması gereken önemli

organ polimorfizmini yansitır.

Received / Geliş Tarihi : 11.04 .2 Accepted / Kabul Tarihi : 23.06.2021 Available Online /

Çevrimiçi Yayın Tarihi : 09.07.2021
Anahtar kelimeler: Timus bezi; sıçanlar; histoloji; ultrastrüktür; deney. 


\section{INTRODUCTION}

The immune system, as one of the central systems of homeostasis control, provides the physiological mechanisms for its regulation and takes direct part in the development of compensatory and adaptive reactions $(1,2)$. Thymus is a central organ of lymphopoiesis, hematopoiesis and immune protection of the organism in all vertebrates, and is often studied in experimental biomedical research projects (3-8). The uniqueness of the thymus morphology lies in the significant heterogeneity of its cellular composition, which forms epithelial, mesenchymal, vascular, hematopoietic cells: T- and Blymphocytes, macrophages, dendritic cells, etc. (9-11). The development of T-lymphocytes and the formation of recirculating pool of these cells is the main function of the thymus $(12,13)$.

Numerous studies have shown that morphological changes at the ultrastructural level form the initial link of any pathogenetic mechanism. Therefore, there is no damaging factor that would not lead to structural changes in the cell. This attaches particular importance to further in-depth study of the submicroscopic organization of thymus cells in the normal conditions in connection with the search for key morphological equivalents of its normal function and the development of common criteria that can be used as benchmarking comparisons in conducting experimental medical and biological research.

A deep understanding of the normal cytoarchitectonics of the thymus and the morphology of all parts of the functional system: "Bone marrow - thymus - spleen lymph nodes" - is extremely necessary for understanding the formation of the ultimate adaptive effect - immune protection of the organism. Topicality of the study is due to the need to clarify the data on the contribution of each type of thymus cells in the formation of its structure.

The aim of the research was to determine the specifics of localization and ultramicroscopic structure of thymus cells in male mature Wistar laboratory rats.

\section{MATERIAL AND METHODS}

Experimental research was carried out on the basis of the laboratory center of morphological research of Sumy State University (Sumy, Ukraine). The institutional and national guide for the care and use of laboratory animals was followed (Ethics committee of Sumy State University, date of approval 02.03.2020, Protocol №2/2).

\section{Experimental Design}

The experiment was conducted on 10 mature male laboratory rats, weighing 130-150 g. The maintenance and manipulation of animals was carried out in compliance with the requirements of bioethics and the "General Ethical Principles of Animal Experiments" adopted by the First National Congress on Bioethics (Kyiv, 2001), the requirements of the "European Convention for the Protection of Vertebrate Animals Used for Experimental and Other Scientific Purposes" (Strasbourg, 1986), the principles of the Helsinki Declaration on the Human Approach to Animals. All rodents were kept in conventional environment of vivarium with the usual food and water intake.

\section{Electron Microscopy}

After animals' decapitation and dissection of the chest wall under thiopental anesthesia thymus was extracted. Samples of the investigated organ tissue were first fixed in glutaral aldehyde (by Karnovsky), and then in $1 \%$ solution of tetraoxide osmium (by Palade). Subsequently, the samples were made through ethanol solutions of increasing strength and filled into a mixture of epoxy resins followed by polymerization. Semi-thin $(0.5-1 \mu \mathrm{m})$ and ultrathin sections $(0.05-0.2 \mu \mathrm{m})$ were made on a microtome UMTP4 (Ukraine), which were stained with $1 \%$ methylene blue solution with the addition of $1 \%$ sodium tetraborate solution. Histological analysis and photographic recording were performed using Olympus light microscope (Japan) and DSM 510 camcorder with magnification in 1000 times. Ultra-thin sections were enhanced with uranyl acetate and lead citrate and investigated by electron microscope PEM-125 K (Ukraine).

\section{RESULTS}

With a detailed study of the semi-thin sections in the thymus lobules, according to the international classification of histological terms (5), morphologically distinct zones that had the specifics of the cellular structure organization were clearly identified: the cortical substance in the sections was more intensively stained, thymocytes were densely placed, the medulla was stained less intensively since contained fewer thymocytes (Figure 1b, Figure 2). The zones formed a lobe covered with a capsule (Figure 1a). The thin capsule of the connective tissue extended into small trabeculae, which partially divided the thymus into adjacent lobules of different sizes, extending from the periphery to the center of the lobes. In these partitions there were blood vessels and nerves. Between the capsule and trabeculae was a carrier carcass consisting of a network of epithelioreticular cells, which together with thymocytes are one of the major cellular components of the thymus. Between the cortex and medulla, an unclear boundary was determined, characterized by the presence of blood vessels (preferably arterioles) with a small amount of perivascular connective tissue, mature and immature thymocytes (Figure 3).

Important functional zones of thymus include intralobular perivascular spaces $(14,15)$. These spaces were located close to the intercellular trabeculae and were limited from one side by a powerful, thickened basal membrane of blood vessels, from another side by a basal membrane of cortical and medullar epithelioreticular cellular nets. Intralobular perivascular cortical areas, together with the endothelium of the blood capillaries, are considered to be the structural basis of the blood-thymus barrier. The latter is defined as a functional and selective barrier between thymocytes and blood, into which, in addition to epithelial reticular cells, also include macrophages and perivascular thymocytes. In the medullar substance, this structure was not determined in its entirety.

It is generally recognized that in the cortical zone, the following cells are morphologically differentiated: epithelioreticulocytes cells (forming a cortical cellular network), macrophages, nursing cells, precursor cells (prolymphocytes, lymphoblasts) (5).

In the cortical zone of the intact rats' thymus were found epithelioreticular cells of the polygonal form (Figure 1a) with cytoplasm sprouts and a light euchromatic nucleus of irregular shape, with small lumps of heterochromatin, often 


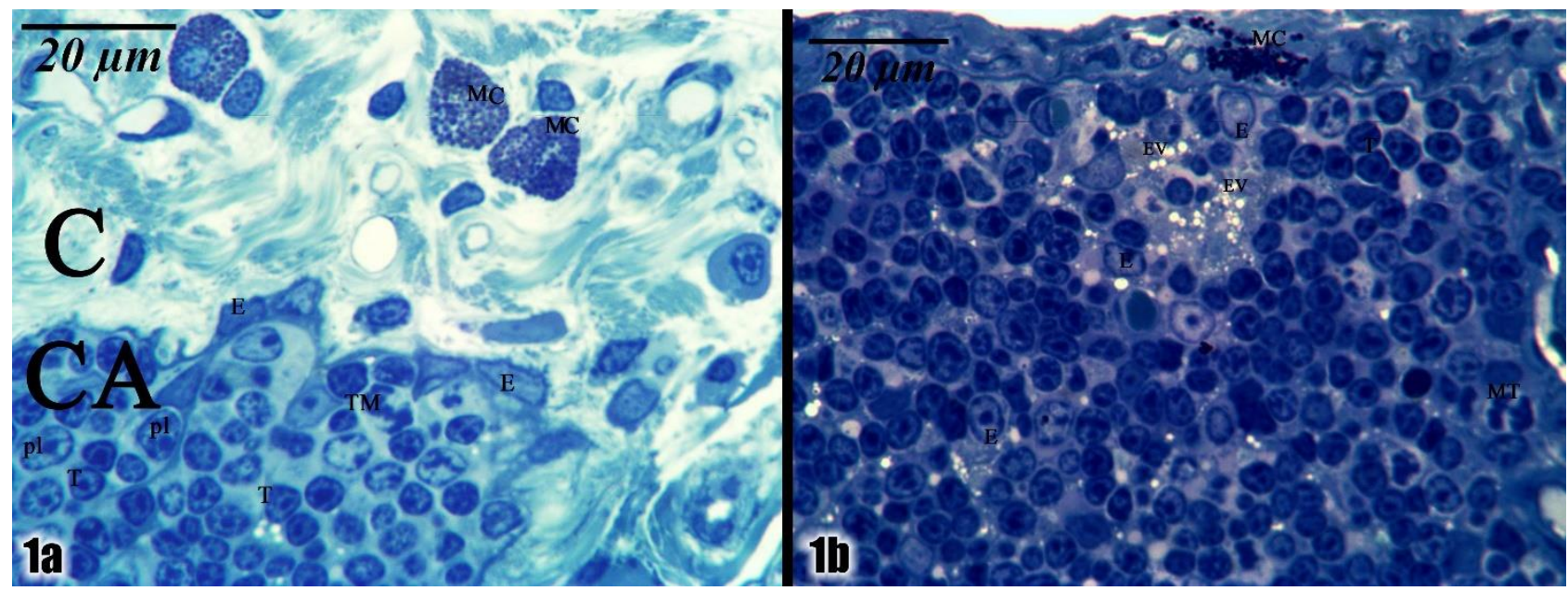

Figure 1a. Capsule (C) and cortex (CA) of the rat's thymus. Thymocytes (T), epithelioureticulocyte (E), mastocytes (MC), prolymphocytes (pl); 1b. Capsule of the rat's thymus. Thymocytes (T), epithelioureticulocytes (E), epithelioureticulocytes with vacuoles (EV), mastocyte (MC), cell in the stage of mitosis (MT). Semi-thin slice. Methylene blue stain

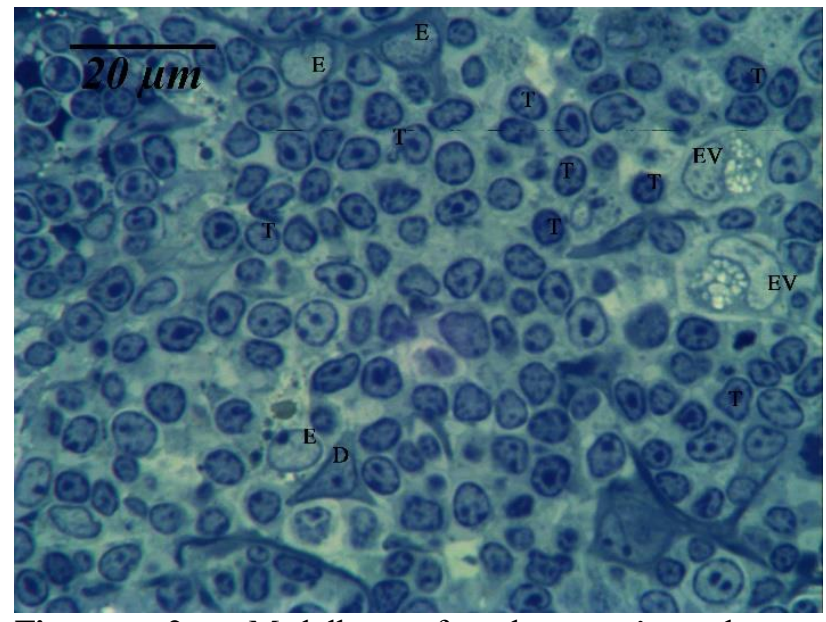

Figure 2. Medulla of the rat's thymus. Epithelioureticulocytes with vacuoles (EV), Thymocytes (T), epithelioureticulocytes (E), dendritic epithelioureticulocyte (D). Semi-thin slice. Methylene blue stain

with a developed nucleolus. The cytoplasm revealed mitochondria, the Golgi apparatus, and ribosomes. There were epithelioureticular cells with a lighter nucleus and cytoplasm without vacuoles. Alongside the nuclei, thin bundles of keratin tonofilaments were determined (Figure 4a, 4b). We also observed epithelioureticular irregular cells with a dark nucleus and a vacuolated cytoplasm. Vacuoles were often filled with fine-grained content (Figure 4c, 4d). Cells were located singly in both the cortical and medullar areas (Figure 1b).

In medullary zone the following cells are morphologically differentiated: epithelioreticulocytes (forming a cortical cellular network), macrophages, dendritic cells, precursor cells (prolymphocytes, lymphoblasts), as well as Hassall's corpuscles (5).

In the corticomedular zone, there were epithelioreticular cells with a rounded nucleus that contained heterochromatin lumps and the nucleolus. The cytoplasm was depleted by organelles, there were isolated ribosomes,

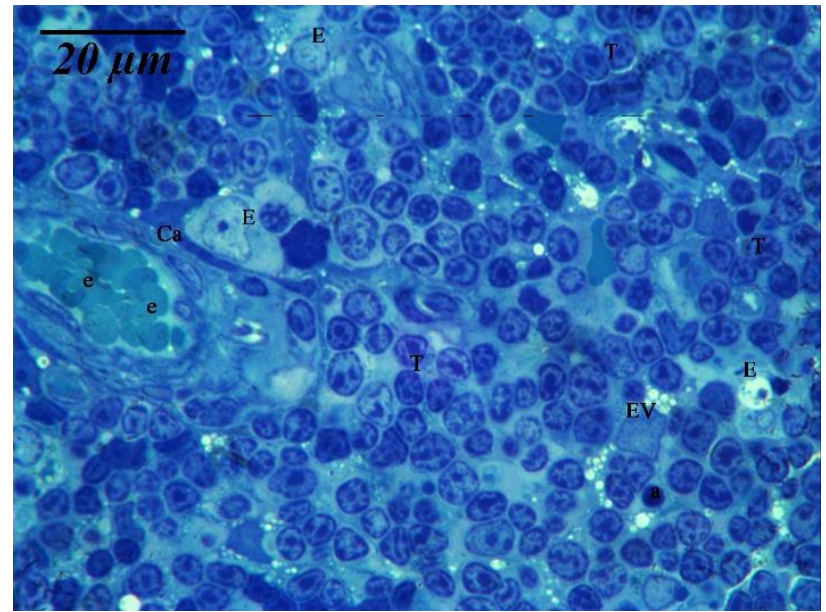

Figure 3. Cortico-medullar zone of the rat's thymus. Hemocapillar (Ca), Thymocytes (T), epithelioureticulocytes (E), epithelioureticulocyte with vacuoles (EV), erythrocyte in a hemocapillar lumen (e). Semi-thin slice. Methylene blue stain

mitochondria, Golgi apparatus, small clusters of tonofilaments (Figure 4e).

Epithelioreticulocytes of the thymus medulla were more numerous. More often occurred large cells sizes with bulky, not clearly expressed cytoplasmic processes. The nuclei of these cells had a crescent or irregular shape, with a predominance of euchromatin, contained nucleolus. The ultrastructural organization of these cells has shown high metabolic and secretory activity, as in their cytoplasm, generally, there were numerous transport vesicles, expanded rough endoplasmatic reticulum profiles Golgi apparatus, vacuoles located in a separate section of the cytoplasm near the nucleus (Figure 4f).

All thymic epithelioreticular cells were characterized by the presence of desmosomes and tonofilaments.

In the thymic medullary zone of the intact mature rats occasionally encountered Hassall's corpuscles (clusters of concentrically located flattened epithelial cells), which are considered one of the morphological markers of this zone. 

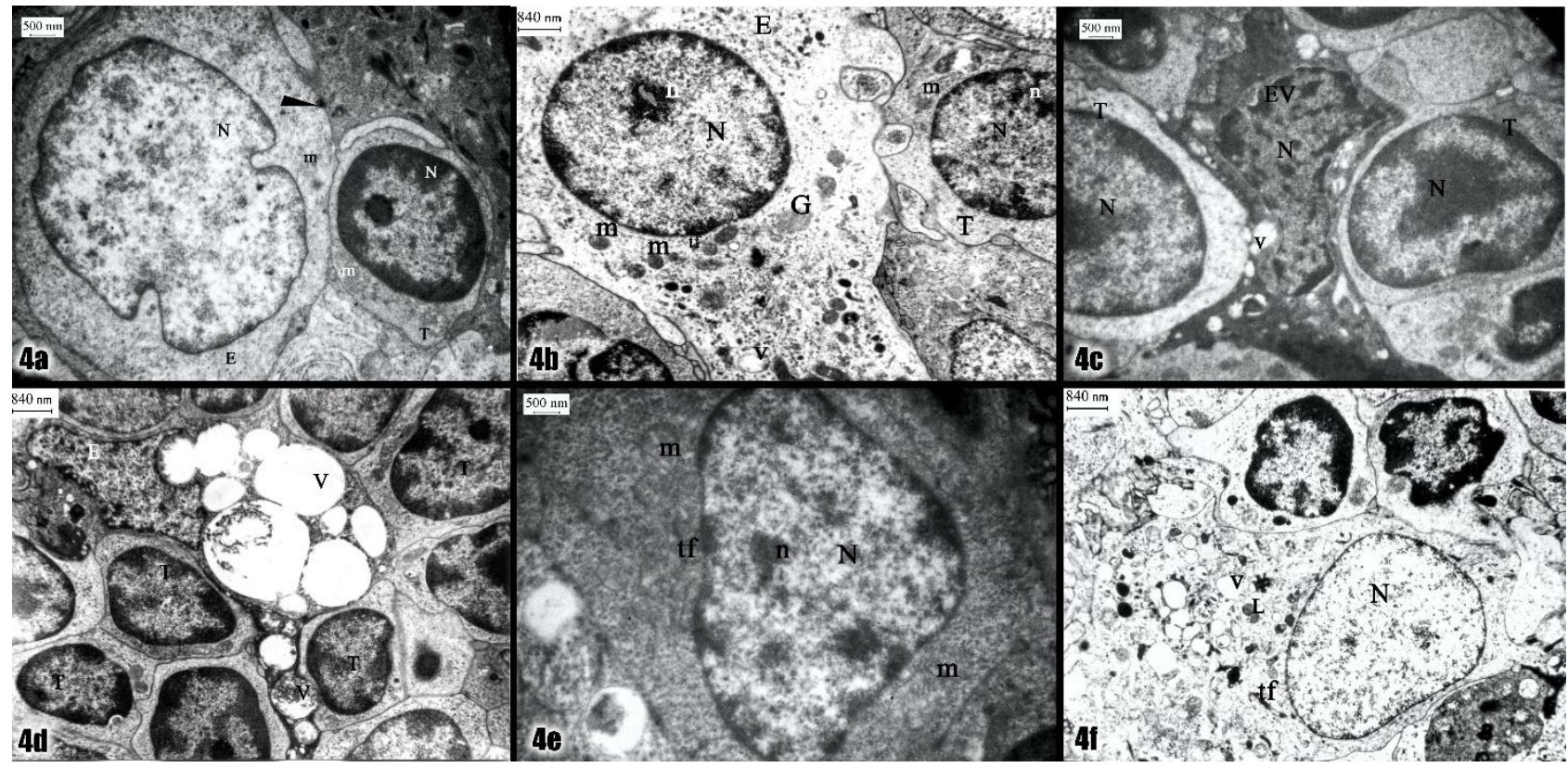

Figure 4(a,b,c,d,e,f). Polymorphism of epithelioreticulocytes of thymus in rats. Thymocyte (T), epithelioureticulocyte (E), epithelioureticulocyte with vacuoles $(\mathrm{EV})$, nucleus $(\mathrm{N})$, nucleolus $(\mathrm{n})$, vacuoles $(\mathrm{V})$, mitochondria $(\mathrm{m})$, keratin tonofilaments (tf), lysosomes (L), black triangular arrow - desmosome (D), Golgi apparatus (G). Electronograph

Superficial layer of the corpuscles had irregular contours, was formed by flattened light structures that resembled epithelial cells without nuclei, but with fragments of ER, keratin tonofilaments, and single lysosomes. The structures of the superficial layer of the corpuscles had a small number of pronounced cytoplasmic processes. All visualized Hassall's corpuscles did not have a keratin nucleus and contained 1-2 epithelial cells in the center, which allows them to be identified as progressive; according to the classification of the stages of the development of Hassall's corpuscles, proposed by Beloveshkin AG (14). Centrally located epithelial cells had more often oval shape with uneven contours of light or dark enough broad cytoplasm, which contained isolated autophagosomes, oval or rounded form mitochondria, small lysosomes, keratin tonofilaments. Cell nuclei were often euchromatin with compactification of chromatin near the nuclear membrane, had an elongated shape, unequal contours with pronounced invaginations, which frequently split the nucleus into several blades. In the immediate proximity to Hassall's corpuscles, thymocytes were predominantly identified that did not form dense contacts with the corpuscles (Figure 5a, 5b).

During the investigations of semi-thin slices and electronographs were found only single epithelial cells which morphologically reminded nurse cells and contained 1-2 thymocyte in their invaginations.

In capsule were determined tissue basophils (mast cells). They formed groups of 3-6 cells in an intermittent chain or located apart (Figure 1a, 1b).

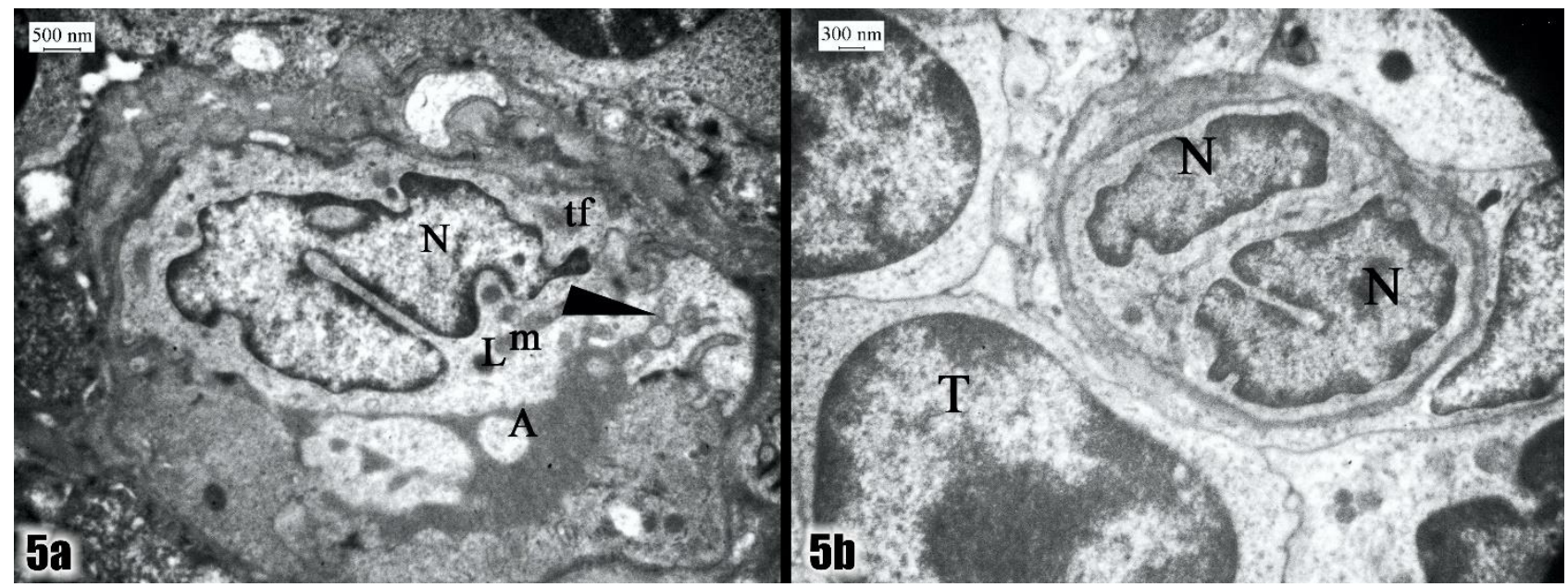

Figure 5a. Hassall's corpuscle of the rat's thymic medulla. The nucleus (N) of the epithelial cell with deep invaginations, mitochondria (m), autophagosome (A), black arrow - cytoplasmic processes, keratin tonofilament - (tf), (L) - lisosome; 5b. Progressive body of the Hassall's corpuscle of the rat's thymic medulla. Thymocyte (T), nucleus (N) of the epithelial cell with deep invaginations. Electronograph 
Underneath the capsule between single epithelioreticulocytes there were densely located, less differentiated lymphoid cells (prolymphocytes and lymphoblasts) that are precursors of T-lymphocytes (Figure 1a). The cells were predominantly round or oval shape with a rounded or oval nucleus, with one or two nucleoli. Chromatin was homogeneous but occurred denser areas of heterochromatin under the nuclear membrane. Narrow cytoplasmic rim surrounded the nucleus, oval mitochondria, single or multiple ribosomes, Golgi apparatus and refined ER were often visualized (Figure 6a). Perinuclear zone had less electron density. They were characterized by high mitotic activity.
Segregate prethymocytes were at different stages of mitosis (Figure 6b).

During the study of semithin and ultrathin slices in the cortex and medulla of thymus, there were segregate apoptotic thymocytes with peculiar changes in the nucleus and cytoplasm. The consolidation of the nucleus with a change in the structure of its boundaries and the waviness of its contours, the condensation, and shrinkage of the cytoplasm were distinguished. An aggregation of nuclear chromatin in the form of various sizes of debris was observed. In some apoptotic lymphocytes, the condensed chromatin was located in a crescent form, sometimes filling the whole nucleus (Figure 7).

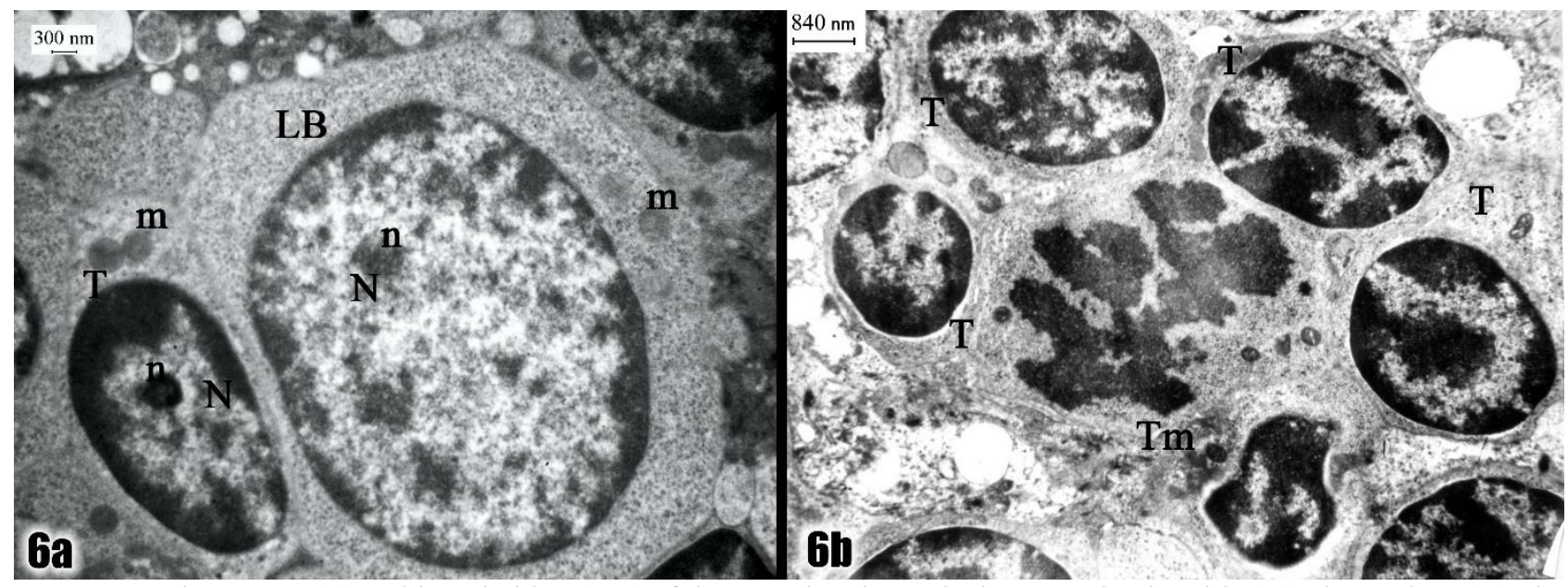

Figure 6a. Thymocyte (T) and lymphoblast (LB) of the rat's thymic cortical zone. Mitochondria (m), the nucleus (N), the nucleolus (n); 6b. Thymocytes (T) of the rat's thymic cortical zone. In the center located the cell in the mitosis stage (Tm). Electronograph

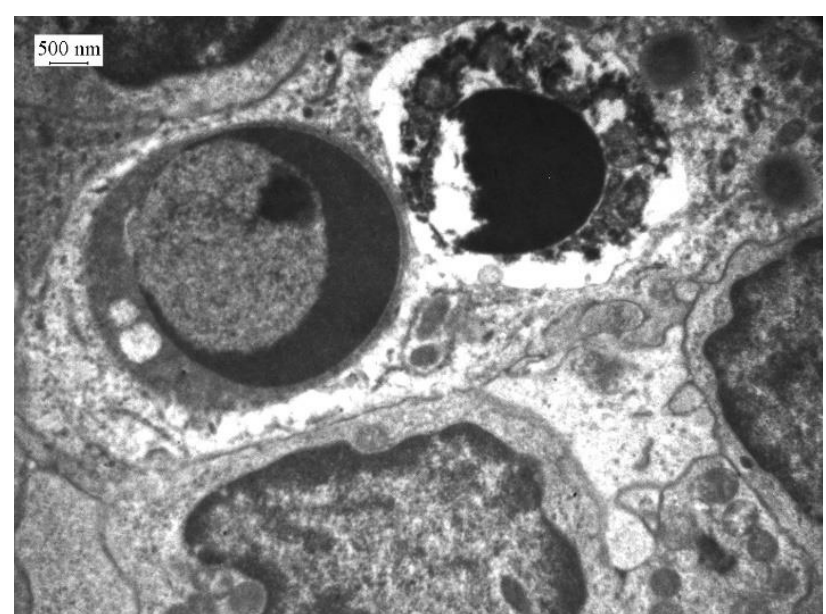

Figure 7. Apoptosis of thymocytes in the corticomedullary zone of the rat's thymus. Electronograph.

Typical plasmocytes were present among thymocytes in electronograms, as evidenced by the large eccentrically placed oval nucleus of the cell, where euchromatin dominated, a nucleus with a ribosomal aureole located. The cells had a well-developed Golgi apparatus, polysomes, and large, well-preserved membrane components of the mitochondria, which adhered tightly to the short tubules of a well-developed rough ER.
In the structure of different thymic zones, macrophages were presented. In the subcapsular zone of intact adult rats, single macrophages were observed, which represented large cells with a small amount in the cytoplasm of lysosomes and small vesicles that had electron-dense content. (Figure 8a).

The functional purpose of the subcapsular zone is to provide proliferation and initial stages of maturation of pre-T-lymphocytes (after their migration from the bone marrow) under the influence of appropriate signals from macrophages through the formation of contacts (16-18). Compared with other thymic areas of intact adult rats, the cortical zone was characterized by the highest density distribution of macrophages that were morphologically similar to the macrophages of the subcapsular zone and localized in the perivascular spaces. Quite often occurred macrophages of elongated shape, as well as cells with small sprouts, which resembled pseudopodias (Figure 8b). In the cortex of the thymus, contacts between macrophages and thymocytes, which in some cases were characterized by a large area of contacting cell membranes, were often determined (Figure 8c).

The macrophages of the cortico-medullary zone of thymus morphologically resembled the most resident monocytes: they were mostly round-shaped with a small amount of weakly expressed spherical invaginations of the cytoplasm, often a bean-shape form of the nucleus. 
In the medullary zone of the intact adult rats' thymus, a few macrophages that located freely between thymocytes without contact formation between them were observed. This arrangement is likely to indicate their role as cells, which, together with epithelial cells and dendritic cells, provide microenvironment for antigen-dependent maturation of thymocytes in this zone of thymus $(19,20)$. In general, intact mature rats' macrophages of the thymus different zones were characterized by the following ultrastructural features. The cells had both round and elongated shapes with a rough surface and small protrusions of the cytoplasm, which resembled pseudopodias. On the cells' surface, there were invaginations of different sizes and in different quantity. The nuclear-cytoplasmic ratio was close to 1.0. Often were observed well-expressed nucleoli. Macrophages were characterized by developed intracellular membrane structures. Rough ER had the form of branched channels. The Golgi apparatus was formed by cisternaes, which were combined with small-sized vesicles. In the cytoplasm of all cells were determined, mostly small, sometimes larger granules, which resembled monocytes granules. Also, in individual macrophages, the elements of the cytoskeleton were identified: fibrillar and tubular structures. The mitochondria in the vast majority of cells were small and had close to round shape. In the cytoplasm of all macrophages, more or less pronounced primary and secondary lysosomes were detected in different amount, as well as vacuoles of various sizes were often found. Separate macrophages contained in the cytoplasm apoptotic bodies of thymocytes (Figure 8d).

The cytoarchitectonics of the thymus of the investigated rats group was characterized by the presence of dendritic cells (DC). DC were often found in medullary and corticomedullary zones. Few DC were observed in the cortical and subcapsular areas, as well as in perivascular spaces, and segregate DCs were found in connective tissue trabeculaes. Occasionally, DCs were located separately, more often they formed clusters with thymocytes. In such clusters, cells are tightly contacted with membranes, but without the formation of desmosomes and tonofilaments. DC - volumetric cells with electron light cytoplasm, which formed processes (predominantly from 3 to 6), which tended to penetrate more or less deeply between thymocytes. The nucleus was characterized by polymorphism (invagination), the presence of euchromatin with a thin layer of heterochromatin, located along the nuclear membrane. Most often the nucleus was located

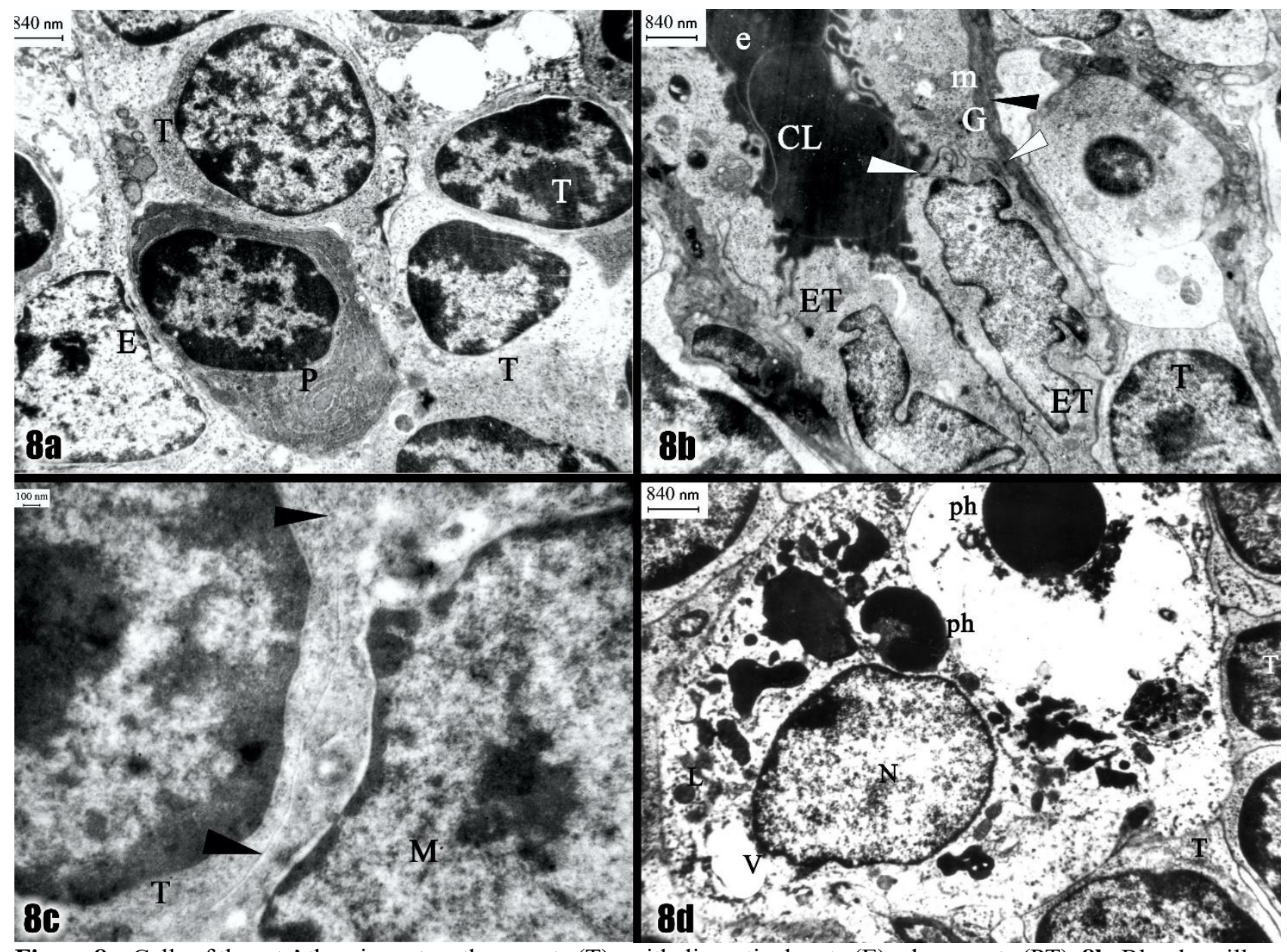

Figure 8a. Cells of the rats' thymic cortex. thymocyte (T), epithelioureticulocyte (E), plasmocyte (PT). 8b. Blood capillary of the rat's thymic cortex. Capillary lumen (CL), erythrocytes (e), thymocyte (T), endotheliocyte (ET), black arrow - basal membrane, white arrow - desmosome, Golgi apparatus (G). 8c. Contact of macrophage cell membranes (M) and thymocyte (T) of the rat's thymic cortex - arrows. 8d. Cells of the rat's thymic cortex: epithelioreticulocyte (E), thymocytes (T), macrophage: phagosome (ph), nucleus $(\mathrm{N})$, lisosome (L), endoplasmatic reticulum (EPR). Electronograph. 
eccentrically and contained a nucleolus. In the cytoplasm of the DC near the perinuclear zone, there were organelles: a developed Golgi apparatus with small-scale vesicles, ER in the form of located peripherally narrow elongated cisternaes, sometimes large enough mitochondria. Also, in the DC cytoplasm, as a rule, were represented lysosomes in a small amount. In the cytoplasm of individual DC, there were vesicular structures that contained picnotial nuclei of lymphocytes (presumably phagolysosomes). Occasionally, in the cytoplasm of the DC, a few spindleshaped formations similar to Birbeck granules located in the central part of the cell were observed (Figure 9).

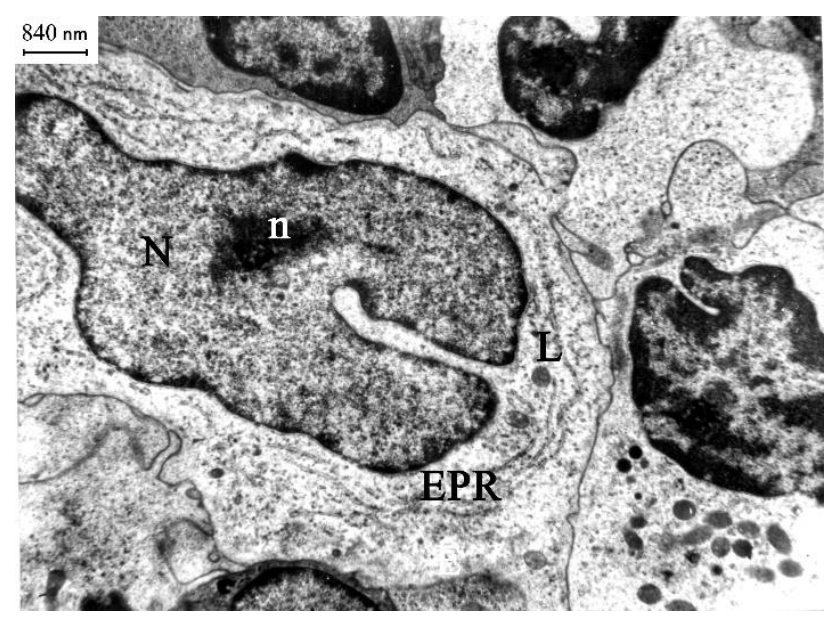

Figure 9. Dendritic cell (D): nucleus (N), nucleolus (n), lisosome (L), endoplasmatic reticulum (EPR). Electronograph

\section{DISCUSSION}

In the scientific literature, there are several opinions concerning the classification of the structural and functional zones of the thymus lobules. Some authors distinguish within the thymic lobule four zones: the outer subcapsular, internal cortical, medullar and perivascular spaces (21). Other authors in their works describe three zones: cortical, cortico-medullar and medullar $(11,22,23)$. In studies of the last 10 years presumably the authors describe five zones in the thymus lobe, three of which are localized in the cortical substance; subcapsular, central cortical zone and marginal cortical zone, and two - in the medulla; marginal medullar zone and central medullar zone (24-26).

In our opinion, in the description of the thymic ultrastructural structure, the most appropriate is to use histological classification, but in order of further zones detailing, structures and cells location, additional definitions of different compartments can be used.

An important morphological element of the thymus lobe, which, in our view, is subject to mandatory ultrastructural evaluation, is a blood-thymus barrier. The latter is defined as a functional and selective barrier between thymocytes and blood, which, in addition to epithelioreticulocytes, also includes macrophages and perivascular thymocytes $(5,25,27,28)$. The blood-thymus barrier protects thymocytes from circulating macromolecules (antigens). According to Pearse G (23) in this area, along with small blood capillaries, postcapillary venules with high endothelium are detected. There are also dendritic cells, thymocytes, B-lymphocytes, plasma cells. A detailed study of the blood-thymus barrier under the normal conditions allows us to get a proper idea of the cohesion between the thymus tissue and the structures of the microcirculatory bed.

By ultramicroscopic features, 6 types of epithelial cells are distinguished. Cells of 1 type limit the capsule, partitions, and surround perivascular spaces of the cortical substance. 2 and 3 type cells are localized in the cortical substance. Type 4 cells are located in the corticomedullar zone; cells of 5 and 6 types are stromal cells of the thymic medulla and thymic bodies. Based on the results of immunohistochemical studies, four main types of epithelial cells are identified: subcapsular (paraseptal, perivascular), cortical, medullary, and Hassall's corpuscles (16). Takahama et al. (11) suggest to distinguishing between 7 types of epithelial cells in the thymus. According to our ultrastructural data polymorphism of the mature rats' thymus is forming presumably in account of known existed 6 types of epithelioreticular cells.

Hassall's corpuscles are not numerous but compulsory component of the microenvironment of the medulla of rats' thymus. A thorough analysis and synthesis of literature on origin, morphological and functional features of Hassall's corpuscles were made by Beloveskin AG (14) in the monograph "The System Organization of Hassall's Corpuscles" (2014). The author proposed the classification of the stages development of corpuscles, according to which distinguished: progressive, mature and regressive bodies. Also, the author, according to our vision, is quite successfully, substantiated and detailed the concept of the Hassall's corpuscles systematic organization. At the heart of this concept lies the close interaction of all structural elements of the corpuscle, which is characterized by a large variety of information exchange, necessary for the harmonious work of individual parts of the body's immune protection system (for example, the removal of autoreactive thymocytes, etc.). At the same time, the systemforming factor, according to the author, is the process of synthesis, mobilization, and transfer of tissue-specific autoantigens to dendritic cells that are in direct contact with the Hassall's corpuscles (14).

Concerning the age dynamics of the number and agerelated morphological changes in Hassall's corpuscles, in humans, in particular, some authors note that the number of corpuscles increases until the period of puberty, after which it non-linearly decreases to an average of 70 years when again there is a slight increase. As the age-old involution of the thymus also changes the morphology of the Hassall's corpuscles, which can be gigantic in size and undergo cystic degenerative changes. All these changes are a reflection of age-related rearrangements in the cellular microenvironment of the thymus (21).

An important element of the thymic cytoarchitectonics is the nursing cells. According to some authors, nursing cells are located in the subcapsular zone and in the cortical substance, have deep invaginations, in which there are lymphocytes. Nursing cells are thymic nourishing cells and their cytoplasm penetrating between lymphocytes, can obtain the appearance of very thin and elongated bands. Typically, such cells contain 10-20 or more lymphocytes. Nursing cells are capable of producing thymosin. 
Thymocytes are forming the most numerous and diverse by morphology and size of the thymus cell population. It is believed that thymocytes of the cortical substance migrate to the bloodstream, without passing the medulla. These lymphocytes differ in the composition of receptors from $\mathrm{T}$ lymphocytes of the medulla. With blood flow they enter the peripheral organs of lymphocytopoiesis -lymph nodes and spleen, where they ripen, forming subpopulations. The thymocytes of the medulla are recirculating pool and can enter the bloodstream and proceed from the blood flow through the postcapillary veins (15).

Thymus macrophages originate from precursors of the myeloid line of the bone marrow and together with monocytes and dendritic cells form a mononuclear phagocytic system. Monocyte is considered as a circulating version of phagocytic cells, and the macrophage -as a tissue (resident) version of phagocytic cells (14).

Described by us DC form a unique, genetically and functionally heterogeneous component of the mononuclear phagocytic system and is considered as the main cells that recognize the pathogenic patterns (so-called "DCdetectors") and the presentation of antigens (the so-called "DC-presenters"). DC play a key role in the integration of responses of congenital and adaptive immunity and determine the central and peripheral tolerance of the immune system of the organism. At the heart of the mechanism of central tolerance, formation is the active participation of the thymus DC in the negative selection of $\mathrm{T}$ cells and their subsequent elimination. The origin, ultrastructure, localization, pathways of migration in the body, phenotypic features, and functions of individual subpopulations of DC continue to be studied actively (27). In the majority of the research papers devoted to the question of the origin of DC, published over the past 10 years, the authors have expressed the common opinion that DCs originate from hematopoietic stem cells through a series of stages of the precursor cells within the two histogenetic series: myeloid and lymphoid. Guiliams et al proposed a classification of DC based on their origin, localization, functions and features of the phenotype. According to this classification, the DC have a common predecessor, which in turn comes from the stem cell of the bone marrow. From the common predecessor, two lines of DC develop: the precursors of the classical (myeloid) DC (cDK) and precursors of plasmacytoid DC (pDC). From predecessors of the $\mathrm{pDC}$ under the control of the E2-2 transcription factor develop mature pDC. From the precursors of the $\mathrm{CDC}$, two phenotypes develop: under the control of BAFT3 (Basic leucine zipper transcriptional factor ATP-likes 3) - cDK1, and under the control of IRF4 (Interferon-regulatory factor 4) - cDC2 (22).

\section{CONCLUSION}

To sum up, it should be noted that the features of localization and ultrastructure of rat thymus cells described by us reflect the significant morphological heterogeneity of this organ. The study of certain issues of normal morphology of lymphoid and non-lymphoid thymus cells, their interrelationships, including with vascular structures, can not be described as complete nowadays. Knowledge of normal thymus morphology is a prerequisite for the objective evaluation of data obtained during model experiments.
Ethics Committee Approval: The study was approved by the Clinical Research Ethics Committee of Sumy State University (02.03.2020, 2/2).

Conflict of Interest: None declared by the authors.

Financial Disclosure: None declared by the authors.

Acknowledgements: The research was conducted on the basis of Sumy State University. Hence, the authors are gratefully thankful for the technical support and to the spiritual guidance of the research unit.

Author Contributions: Idea/Concept: OP, VB; Design: OP, SD, VB; Data Collection/Processing: OP, SD, OG; Analysis/Interpretation: OP, SD; Literature Review: OA, EK; Drafting/Writing: OP, OA, EK, VB, OG; Critical Review: OP.

\section{REFERENCES}

1. Alekseev LP, Khaitov RM. [Regulatory role of the immune system in the organism]. Ross Fiziol Zh Im I M Sechenova. 2010;96(8):787-805. Russian.

2. Kvetnoi IM, Yarilin AA, Polyakova VO, Knyaz'kin IV. [Neuroimmunoendocrinology of the thymus]. St. Petersburg: Dean; 2005. Russian.

3. Moroz GA. [Structure of intact males wistar's rats thymus in different age]. Svit Med Biol. 2009;5(3):98102. Russian.

4. Voloshyn MA, Chaikovskyi YuB, Kushch OH. [Basics of immunology and immunomorphology]. Kyev: Zaporizhzhia; 2010. Russian.

5. Federative International Committee on Anatomical Terminology (FICAT). Terminologia Histologica: International Terms for Human Cytology and Histology. Baltimore: Lippincott Williams \& Wilkins; 2008.

6. Prykhodko OO, Hula VI, Yarmolenko OS, Pernakov MS, Sulim LG, Bumeister VI. Microscopic changes in rat organs under conditions of total dehydration. Azerb Med J. 2016;4:95-100.

7. Shyian D, Avilova O, Ladnaya I. Organometric changes of rats thymus after xenobiotics exposure. Arch Balk Med Union. 2019;54(3):422-30.

8. Nagakubo D, Swann JB, Birmelin S, Boehm T. Autoimmunity associated with chemically induced thymic dysplasia. Int Immunol. 2017;29(8):385-90.

9. Hakim FT, Memon SA, Cepeda R, Jones EC, Chow CK, Kasten-Sportes C, et al. Age-dependent incidence, time course, and consequences of thymic renewal in adults. J Clin Invest. 2005;115(4):930-9.

10. Parker GA. Cells of the immune system. In: Parker GA, editor. Immunopathology in toxicology and drug development. Vol 1. Immunobiology, investigative techniques, and special studies. Cham, Switzerland: Humana Press; 2017. p. 95-162.

11. Takahama Y, Ohigashi I, Baik S, Anderson G. Generation of diversity in thymic epithelial cells. Nat Rev Immunol. 2017;17(5):295-305.

12. Iwasaki A, Medzhitov R. Regulation of adaptive immunity by the innate immune system. Science. 2010;327(5963):291-5. 
13. Jiang H, Chess L. How the immune system achieves self-nonself discrimination during adaptive immunity. Adv Immunol. 2009;102:95-133.

14. Beloveshkin AG. [Systemic organization of Hassall's corpuscles]. Minsk, Belarus: Medisont; 2014. Russian.

15. Liu D, Ellis H. The mystery of the thymus gland. Clin Anat. 2016;29(6):679-84.

16. Kinsella S, Dudakov JA. When the damage is done: injury and repair in thymus function. Front Immunol. 2020 Aug 12;11:1745.

17. Breusenko DV, Dimov ID, Klimenko ES, Karelina NR. [Modern concepts of thymus morphology]. Pediatrician (St. Petersburg). 2017;8(5):91-5. Russian.

18. Miller J. How the thymus shaped immunology and beyond. Immunol Cell Biol. 2019;97(3):299-304.

19. Lalić IM, Miljković M, Labudović-Borović M, Milić N, Milićević NM. Postnatal development of metallophilic macrophages in the rat thymus. Anat Histol Embryol. 2020;49(4):433-9.

20. Yuldasheva MT. [Morphological and ultramicroscopic characteristic of timus of laboratory groups of animals of prepubertatny age]. Biology and Integrative Medicine. 2017;4:12-22. Russian.
21. Han J, Zúñiga-Pflücker JC. A 2020 view of thymus stromal clls in $\mathrm{T}$ cell development. J Immunol. 2021;206(2):249-56.

22. Figueiredo M, Zilhão R, Neves H. Thymus inception: molecular network in the early stages of thymus organogenesis. Int J Mol Sci. 2020;21(16):5765.

23. Pearse G. Histopathology of the thymus. Toxicol Pathol. 2006;34(5):515-47.

24. Ivanovskaya TE, Zajrat'yanc OV, Leonova LV, Voloshchuk IN. [Pathology of the thymus in children]. St. Petersburg: Sotis; 1996. Russian.

25. Sapin MR, Nikityuk DB. [Immune system, stress and immunodeficiency]. Moscow: Dzhangar; 2000. Russian.

26. Elmore SA. Enhanced histopathology of the immune system: a review and update. Toxicol Pathol. 2012;40(2):148-56.

27. Bódi I, H-Minkó K, Prodán Z, Nagy N, Oláh I. [Structure of the thymus at the beginning of the 21th century]. Orv Hetil. 2019;160(5):163-71. Hungarian.

28. Caminero F, Iqbal Z, Tadi P. Histology, cytotoxic T cells. In: StatPearls [Internet]. Treasure Island (FL): StatPearls Publishing; 2021. 